\title{
Total phenolic compounds and antioxidant capacity of baru almond and by-products evaluated under optimizing extraction conditions
}

\author{
Patrícia Naves Silva ${ }^{1} \oplus$, Tiago Dias ${ }^{1} \oplus$, Leonardo Luiz Borges ${ }^{2,3}{ }^{\circledR}$, Aline Medeiros Alves-Santos ${ }^{1} \oplus$, \\ Maria Aderuza Horst ${ }^{1}\left[\right.$, Mara Reis Silva ${ }^{1} \mathbb{0}$, Maria Margareth Veloso Naves ${ }^{1}[0$

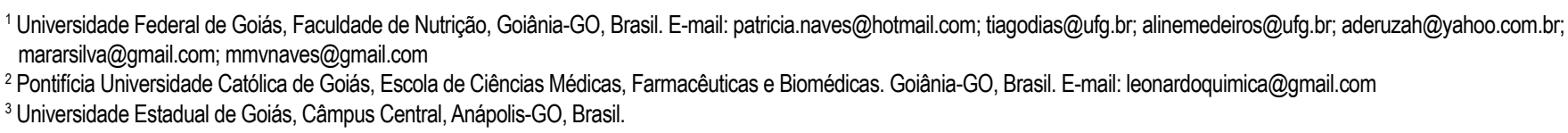

ABSTRACT: The baru almond has a high nutrient and phytochemical density, such as monounsaturated fatty acids, dietary fiber, vitamin $\mathrm{E}$, zinc, and phenolic compounds. This study aimed to optimize the extraction conditions of total phenolic compounds from baru almond (with and without skin) and baru almond skin using a fractional factorial $2^{4-1}$ and the Box-Behnken designs, and to analyze the influence of the extraction factors on total phenolic content and antioxidant capacity (by ABTS, DPPH, and FRAP assays) in the extracts obtained. The optimal extraction conditions were: for whole baru almond (with skin) - $79 \%$ ethanol and $2 \mathrm{mg} \mathrm{mL}^{-1}$ solid-solvent ratio at $85^{\circ} \mathrm{C}$; for baru almond without skin $-68 \%$ ethanol and $20 \mathrm{mg} \mathrm{mL}^{-1}$ solid-solvent ratio during $34 \mathrm{~min}$; and for baru almond skin - $40 \%$ ethanol and $0.2 \mathrm{mg} \mathrm{mL}^{-1}$ solid-solvent ratio at $66{ }^{\circ} \mathrm{C}$. On these conditions, whole baru almond showed high phenolic content and antioxidant capacity, and the almond skin featured about $10 \%$ of phenolics and a very high antioxidant capacity. The experimental designs used revealed the baru almond skin as an abundant source of antioxidant compounds. We recommend the consumption of whole baru almond, and the use of its skin in different food systems.

Key words: bioactive compounds; Dipteryx alata Vog.; natural antioxidant; phytochemicals; polyphenols

\section{Compostos fenólicos totais e capacidade antioxidante da amêndoa de baru e subprodutos avaliados em condições de extração otimizadas}

RESUMO: A amêndoa de baru contém um alto teor de nutrientes e fitoquímicos, como ácidos graxos monoinsaturados, fibra dietética, vitamina $E$, zinco e compostos fenólicos. Este estudo otimizou as condições de extração de fenólicos da amêndoa de baru (com e sem película) e da película da amêndoa usando os delineamentos fatorial fracionado $2^{4-1}$ e Box-Behnken, e analisou a influência dos fatores de extração no conteúdo de fenólicos e na capacidade antioxidante (pelos ensaios ABTS, DPPH e FRAP) nos extratos obtidos. As condições otimizadas de extração foram: para amêndoa de baru integral (com película) - etanol a 79\% e razão sólido-solvente de $2 \mathrm{mg} \mathrm{mL}^{-1}$ a $85^{\circ} \mathrm{C}$; para amêndoa sem película - etanol a $68 \%$ e razão sólido-solvente de $20 \mathrm{mg} \mathrm{mL}^{-1}$ durante 34 min; e para a película da amêndoa - etanol a $40 \%$ e razão sólido-solvente $0,2 \mathrm{mg} \mathrm{mL}^{-1}$ a $66{ }^{\circ} \mathrm{C}$. Nessas condições, a amêndoa de baru integral teve alto conteúdo de fenólicos e capacidade antioxidante, e a película apresentou cerca de $10 \%$ de fenólicos e capacidade antioxidante muito alta. $O$ desenho experimental usado revelou a película como uma fonte abundante de compostos antioxidantes. Recomendamos o consumo da amêndoa de baru integral e 0 uso de sua película em diferentes sistemas alimentares.

Palavras-chave: compostos bioativos; Dipteryx alata Vog.; antioxidante natural; fitoquímicos; polifenóis 


\section{Introduction}

The fruit of baru tree (Dipteryx alata Vog.), a plant native to Cerrado, Brazil, contains a single seed coated by a hard skin. This edible seed is popularly known as baru almond (or baru nut) and consumed roasted, whole, or without skin (Sousa et al., 2011). Baru almond is rich in nutrients, such as monounsaturated fatty acids, dietary fiber, vitamin E, and zinc, and the whole baru almond (with skin) is a source of phenolic compounds and has a high antioxidant capacity (Fernandes et al., 2015; Santiago et al., 2018) compared to other oilseeds (Rodríguez-Bencomo et al., 2015; Ozer, 2017). However, the seed without skin contains significantly lower phenolic compounds content and antioxidant capacity (Lemos et al., 2012). These data suggest that the phenolic compounds of whole baru almond are concentrated in its skin.

Phenolic content and antioxidant capacity are often determined in food extracts and may vary according to the characteristics of the food matrices, food processing conditions, and otherfactors related to the extraction procedure (Bodoira \& Maestri, 2020). Reports on the standardization of the extraction conditions of phenolic compounds are scarce in the literature, because of the considerable number of variables involved in these analyses. Nevertheless, factors as solvent concentration, solid-solvent ratio, temperature, and time have been controlled experimentally in food (Odabas \& Koca, 2016; Bodoira et al., 2019). In this context, factorial designs associated with response surface methodology are valuable statistical tools for defining the best extraction conditions of phenolic compounds, for example, in arecanut (Chavan \& Singhal, 2013), and hazelnut skin (Odabas \& Koca, 2016).

To our knowledge, there is no record in the literature about the polyphenol content and antioxidant capacity of the baru almond skin. Thus, this study aimed to optimize the extraction conditions of phenolic compounds from the baru almond (with and without skin) and the baru almond skin using a fractional factorial $2^{4-1}$ and the Box-Behnken designs. This experimental approach was used to investigate the influence of solvent concentration, solid-solvent ratio, temperature, and time on the total phenolic content and antioxidant capacity in the extracts obtained.

\section{Materials and Methods}

\section{Samples and extracts preparation}

Baru almonds were purchased from a local collector in the municipality of Caiapônia ( $16^{\circ} 50^{\prime} 08.9^{\prime \prime}$ S 51 $\left.54^{\circ} 43.5^{\prime \prime} \mathrm{W}\right)$, located in the Southern region of Goiás State, Brazil, during the harvest period of the fruit (August 2015). The baru almond was roasted in a drying oven ( $140{ }^{\circ} \mathrm{C}$ for $20 \mathrm{~min}$ ). The skin was removed from the almond to obtain the following samples: whole baru almond, baru almond without skin, and isolated skin. These samples were ground and stored at $-20^{\circ} \mathrm{C}$ until analysis.

Baru almond extracts were obtained according to Chavan \& Singhal (2013). Briefly, samples were mixed with different ethanol concentrations and solid-solvent ratios at different temperatures and times, in an ultrasonic bath at $40 \mathrm{kHz}$ and $107 \mathrm{~W}$. The extracts were centrifuged $\left(3000 \times \mathrm{g}, 10 \mathrm{~min}, 25^{\circ} \mathrm{C}\right)$ and filtered. The supernatant was collected and mixed with an ethanol solution to obtain a $10 \mathrm{~mL}$ solution. This solution was used to determine the total phenolic content and antioxidant capacity.

\section{Total phenolic compounds}

The total phenolic content was determined by the FolinCiocalteu method (Singleton \& Rossi, 1965). The absorbance of the solutions was recorded at $765 \mathrm{~nm}$, and the total phenolic content was estimated from the calibration curve of gallic acid (Concentration= [Absorbance -0.0322 ] $/ 0.0088 ; r=$ 0.9991 ) and expressed as $\mathrm{mg}$ of gallic acid equivalents $100 \mathrm{~g}^{-1}$ of fresh weight (mg GAE $100 \mathrm{~g}^{-1}$ ).

\section{Antioxidant capacity}

The 2,2'-azino-bis(3-ethylbenzothiazoline-6-sulfonic acid) (ABTS) method was carried out according to Re et al. (1999). Aliquots $(30 \mu \mathrm{L})$ of the extracts were mixed with 3 $\mathrm{mL}$ of the ABTS solution. After $6 \mathrm{~min}$ at room temperature, the absorbance of the extracts was read at $734 \mathrm{~nm}$. The antioxidant capacity was calculated from the calibration curve of Trolox (Concentration $=[0.6867-$ Absorbance $] / 0.0003 ; r=$ -0.9994).

The antioxidant capacity was also evaluated using the 2,2-diphenyl-1-picrylhydrazyl (DPPH) method (Brand-Williams et al., 1995). An aliquot $(0.1 \mathrm{~mL}$ ) of each extract was added to $3.9 \mathrm{~mL}$ of DPPH solution ( $25 \mathrm{mg} \mathrm{L}^{-1}$ ), and this solution was kept at room temperature for $120 \mathrm{~min}$, in a dim light environment. The absorbance of the extracts was recorded at $517 \mathrm{~nm}$, and the results were calculated from the calibration curve of Trolox (Concentration $=[0.5867$ - Absorbance $] / 0.0005 ; r=-0.9994)$.

Ferric Reducing Antioxidant Power (FRAP) assay was performed according to Benzie \& Strain (1996), with the modifications proposed by Pulido et al. (2000). An aliquot (2.7 $\mathrm{mL}$ ) of the FRAP reagent (acetate buffer $300 \mathrm{mM}, 2,4,6$-tris(2pyridyl)-s-triazine $10 \mathrm{mM}$, and iron chloride $20 \mathrm{mM}$ ) was mixed with $90 \mu \mathrm{L}$ of each extract and $270 \mu \mathrm{L}$ of ultrapure water. After $30 \mathrm{~min}$ at $37^{\circ} \mathrm{C}$, the absorbance was measured at $595 \mathrm{~nm}$. The antioxidant capacity was calculated from the calibration curve of Trolox (Concentration = [Absorbance +0.0073]/0.0013; $r$ $=0.9995)$, and the results were expressed in $\mu \mathrm{mol}$ of Trolox equivalents $\mathrm{g}^{-1}$ of fresh weight $\left(\mu \mathrm{mol} \mathrm{TE} \mathrm{g}^{-1}\right)$.

\section{Experimental design}

A fractional factorial $2^{4-1}$ design was carried out to evaluate the influence of the extraction factors on the dependent variables. The Box-Behnken design was performed with three levels and three independent variables (factors), with five replicates at the central point, totalizing seventeen experiments (Lundstedt et al., 1998). The extraction factors were ethanol concentration $\left(X_{1 \%}\right)$, solid-solvent ratio $\left(X_{2 \mathrm{mg} \mathrm{mL}}^{-1}\right)$, temperature $\left(X_{3}{ }_{\circ}\right)$, and time $\left(X_{3 \mathrm{~min}}\right)$. Each factor was coded at three levels $(-1,0,1)$, representing lower, moderate, and 
higher values (Table 1). The experimental data were fitted by a second-order polynomial model to obtain the regression coefficients and to perform the response surface analysis, according to Equation 1.

$$
\mathrm{Y}=\beta_{0}+\sum_{\mathrm{i}=1}^{\mathrm{k}} \beta_{\mathrm{i}} \mathrm{X}_{\mathrm{i}}+\sum_{\mathrm{i}=1}^{\mathrm{k}} \beta_{\mathrm{ii}} \mathrm{X}_{\mathrm{i}}^{2}+\sum \sum \beta_{\mathrm{ij}} \mathrm{X}_{\mathrm{i}} \mathrm{X}_{\mathrm{j}}
$$

Where: $Y$ is the dependent variable, $X_{i}$ and $X_{j}$ are the independent variables (factors), and $k$ is the number of tested variables $(k=3)$. The regression coefficient was defined by $\beta_{0}$ for interception (constant), $\beta_{i}$ for linear coefficient, $\beta_{i i}$ for quadratic coefficient, and $\beta_{\mathrm{ij}}$ for interaction coefficient of variables i and j.

Analysis of variance (ANOVA) was used to evaluate significant differences between linear and quadratic interactions, and the model fitting of the responses (dependent variables: total phenolic content and antioxidant capacity) was estimated by the determination coefficient $\left(R^{2}{ }_{\text {adj }}\right)$ and by the lack-of-fit. Simultaneous optimization of multiple responses was performed using a global desirability test (Hossain et al.,

Table 1. Experimental Box-Behnken design and coding levels used in the experiments with three independent variables $\left(X_{1}\right.$, $\mathrm{X}_{2}$, and $\mathrm{X}_{3}$ ).

\begin{tabular}{|c|c|c|c|}
\hline \multirow{2}{*}{ Experiment } & \multicolumn{3}{|c|}{ Independent variable } \\
\hline & $X_{1}$ & $X_{2}$ & $X_{3}$ \\
\hline 1 & -1 & -1 & 0 \\
\hline 2 & 1 & -1 & 0 \\
\hline 3 & -1 & 1 & 0 \\
\hline 4 & 1 & 1 & 0 \\
\hline 5 & -1 & 0 & -1 \\
\hline 6 & 1 & 0 & -1 \\
\hline 7 & -1 & 0 & 1 \\
\hline 8 & 1 & 0 & 1 \\
\hline 9 & 0 & -1 & -1 \\
\hline 10 & 0 & 1 & -1 \\
\hline 11 & 0 & -1 & 1 \\
\hline 12 & 0 & 1 & 1 \\
\hline 13 & 0 & 0 & 0 \\
\hline 14 & 0 & 0 & 0 \\
\hline 15 & 0 & 0 & 0 \\
\hline 16 & 0 & 0 & 0 \\
\hline 17 & 0 & 0 & 0 \\
\hline \multicolumn{4}{|c|}{ Established values for the samples } \\
\hline \multicolumn{4}{|c|}{ Whole baru almond } \\
\hline-1 & 60 & 2 & 45 \\
\hline 0 & 75 & 5 & 65 \\
\hline 1 & 90 & 8 & 85 \\
\hline \multicolumn{4}{|c|}{ Baru almond without skin } \\
\hline-1 & 65 & 20 & 5 \\
\hline 0 & 75 & 40 & 20 \\
\hline 1 & 85 & 60 & 35 \\
\hline \multicolumn{4}{|c|}{ Isolated skin } \\
\hline-1 & 40 & 0.2 & 45 \\
\hline 0 & 60 & 0.4 & 65 \\
\hline 1 & 80 & 0.6 & 85 \\
\hline
\end{tabular}

$\mathrm{X}_{1}=$ ethanol concentration $(\%) ; \mathrm{X}_{2}=$ solid-solvent ratio $\left(\mathrm{mg} \mathrm{mL}^{-1}\right) ; \mathrm{X}_{3}=$ temperature $\left({ }^{\circ} \mathrm{C}\right)$ for whole baru almond and isolated skin, and time $(\mathrm{min})$ for baru almond without skin.
2011), and the correlation between the dependent variables was tested by the Pearson coefficient $(p<0.1)$. The statistical analyses were performed using Statistic software, version 7.0, and Design-Expert, version 11.

\section{Results and Discussion}

\section{Model fitting}

According to the fractional factorial design, ethanol concentration, solid-solvent ratio, and temperature were the independent variables that influenced the total phenolic content and antioxidant capacity for whole baru almond and isolated skin ( $p<0.05$ ). For baru almond without skin, the temperature was not a significant factor. The fractional factorial design is a useful tool for an experimental design that the behavior of the extraction process is unknown. This tool enables the factors selection influencing the responses, as well as the reduction of the experiments number required to determine the optimum extraction conditions (Candioti et al., 2014).

The optimization of the extraction process was carried out using a second-order polynomial model. The experimental results showed interactions between linear and quadratic coefficients for all responses, and the independent variables showed a high predictive power for estimating the total phenolic content and antioxidant capacity. The values of the adjusted determination coefficient $\left(R^{2}{ }_{\text {adj }}\right)$, from 0.93 to 0.99 (Table 2), indicated a strong correlation between the experimental and predicted values of the responses. Values of $\mathrm{R}^{2}$ adj above 0.8 are usually recommended for chemical studies (Lundstedt et al., 1998), and it is used for evaluating the quality of the model fitting. In addition, the polynomial model contribution was significant $(p<0.0032)$ and the lackof-fit was no significant $(p>0.05)$. However, the total phenolic

Table 2. Regression coefficients of the second-order polynomial model for total phenolic content and antioxidant capacity of whole baru almond, baru almond without skin and isolated skin.

\begin{tabular}{lccc} 
& \multirow{2}{*}{ Variable } & Model & \multicolumn{2}{c}{ Lack-of-fit } \\
\cline { 3 - 4 } & p-value & p-value & $\mathbf{R}^{2}{ }_{\text {adj }}$ \\
\hline Whole baru almond & & & \\
TPC & 0.0002 & 0.0073 & 0.9811 \\
\hline ABTS & 0.0032 & 0.0003 & 0.9972 \\
DPPH & $<0.0001$ & 0.8585 & 0.9989 \\
FRAP & $<0.0001$ & 0.2972 & 0.9991 \\
\hline Baru almond without skin & & & \\
TPC & 0.0001 & 0.0229 & 0.9994 \\
ABTS & $<0.0001$ & 0.2249 & 0.9985 \\
DPPH & $<0.0001$ & 0.2304 & 0.9993 \\
FRAP & $<0.0001$ & 0.4631 & 0.9557 \\
\hline Isolated skin & & & \\
TPC & 0.0003 & 0.6592 & 0.9328 \\
ABTS & 0.0012 & 0.1557 & 0.9593 \\
DPPH & $<0.0001$ & 0.7575 & 0.9960 \\
FRAP & $<0.0001$ & 0.3255 & 0.9885 \\
\hline TPC: & & & \\
\hline
\end{tabular}

TPC: total phenolic content (mg of gallic acid equivalents $100 \mathrm{~g}^{-1}$ of fresh weight); $A B T S$, $\mathrm{DPPH}$ and FRAP ( $\mu \mathrm{mol}$ of Trolox equivalents $\mathrm{g}^{-1}$ of fresh weight). 
content in the whole baru almond and baru almond without skin, and the antioxidant capacity (ABTS) in whole baru almond presented significant lack-of-fit $(p<0.05)$ (Table 2$)$.

Thus, the statistical models generated were able to explain the influence of the main factors affecting the extraction efficiency of the phenolic compounds in whole baru almond and baru almond without skin, and the antioxidant capacity by the ABTS method. The study showed a good fit with the experimental data, and these results indicate that the model employed can be used to predict the responses. A good fit of the model was reported in a study with arecanut $\left(R^{2}\right.$ adj $=0.95$ for TPC; $R^{2}$ adj 0.97 for FRAP) (Chavan \& Singhal, 2013), and with hazelnut skin ( $R^{2}{ }_{\text {adj }}=0.94$ for TPC) (Odabas \& Koca, 2016).

\section{Effect of extraction factors on total phenolic content}

For whole baru almond, increasing the ethanol concentration and reducing the solid-solvent ratio yielded higher values of the total phenolic content ( $p<0.0001)$ (Figure 1a) than did other combinations of the experimental conditions. In contrast, decreasing the ethanol concentration, and employing extraction times above $30 \mathrm{~min}$, increased the recovery of the total phenolic contents from the baru almond without skin (Figure 1b). The sample mass reduction was also significant when combined with the decrease in ethanol, at $20 \mathrm{~min}(\mathrm{p}<0.001)$. Ethanol, a low-toxicity solvent with hydrophilic properties, is used to extract bioactive compounds under experimental and industrial conditions (Shi et al.,
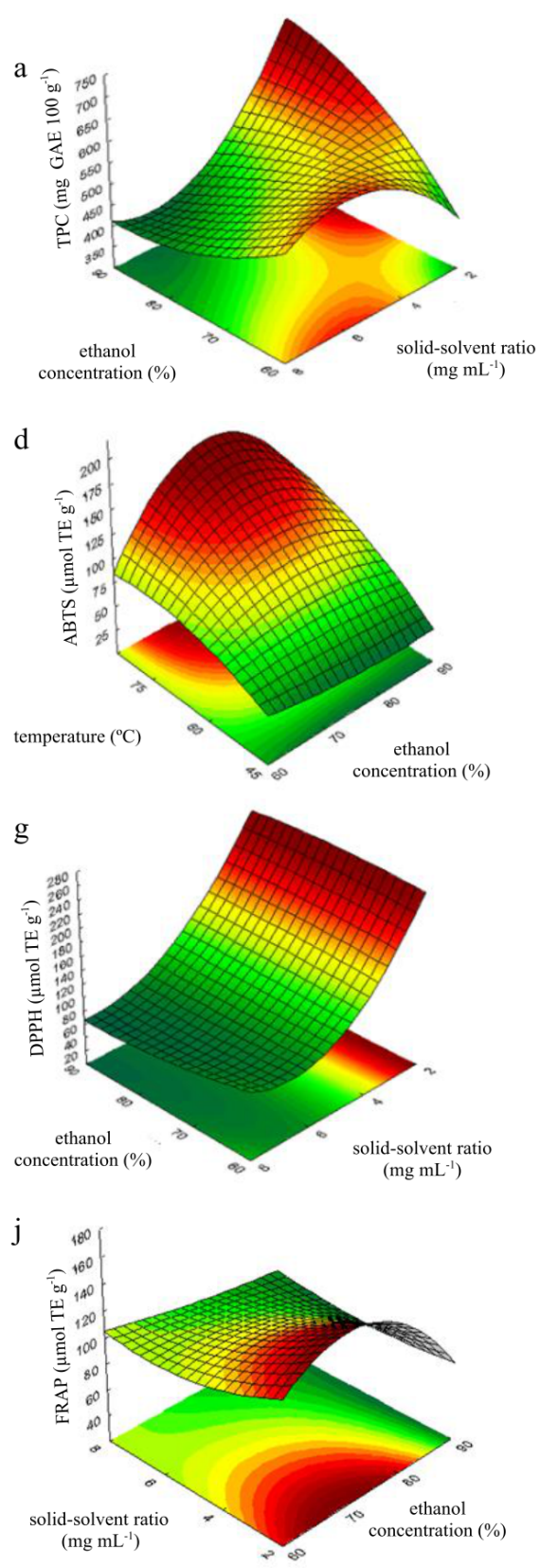

b

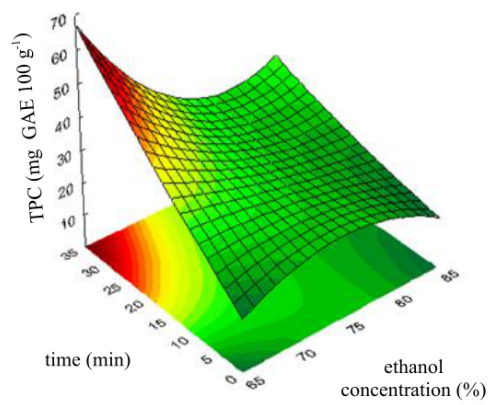

e

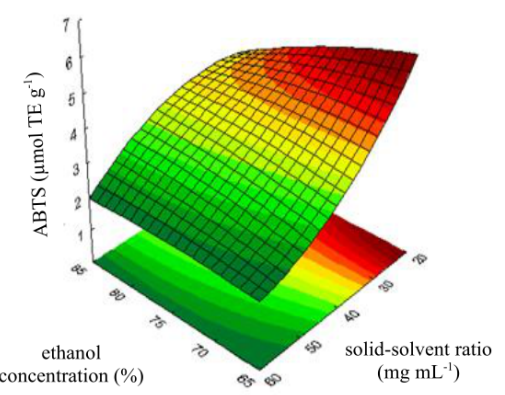

h

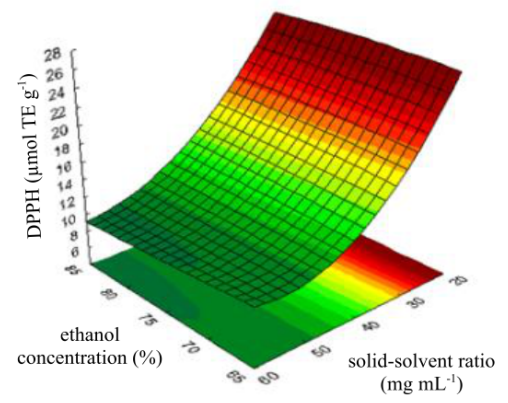

k

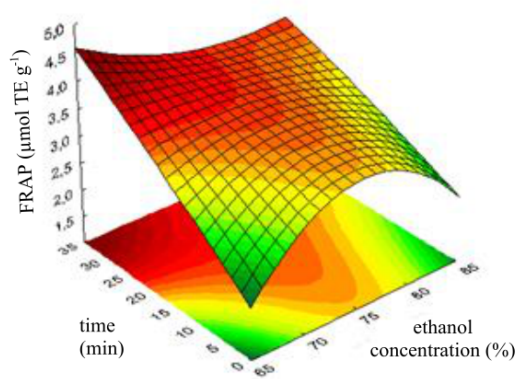

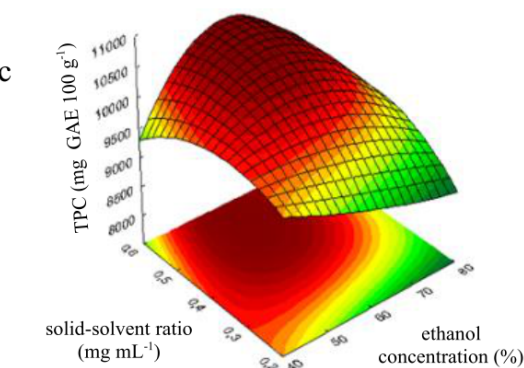

f
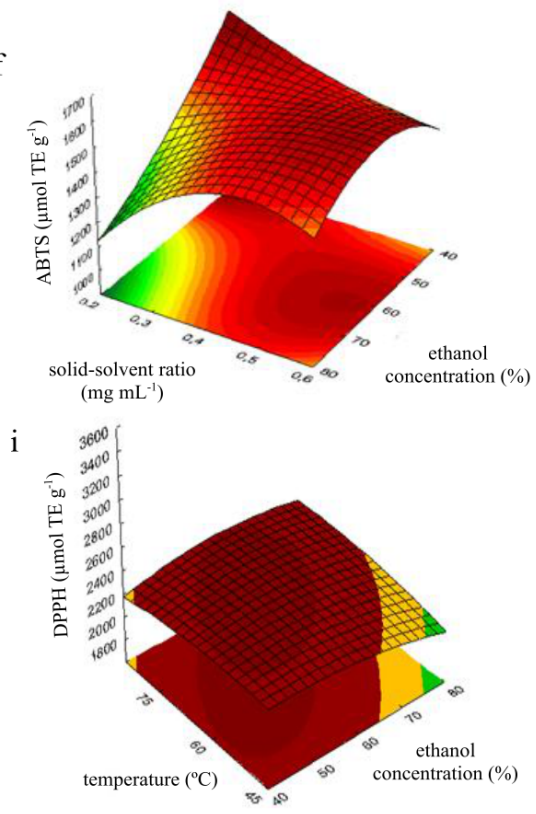

1

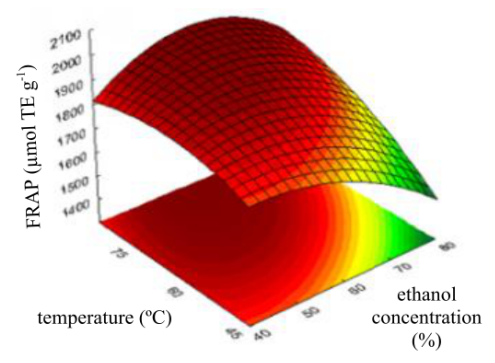

Figure 1. Effect of interactions among extraction factors (solvent concentration, solid-solvent ratio, temperature, and time) on total phenolic content (TPC) and antioxidant capacity (by ABTS, DPPH, and FRAP assays) in whole baru almond (a, $d, g$, j), baru almond without skin (b, e, h, k), and isolated skin (c, f, i, l). GAE: gallic acid equivalents; TE: Trolox equivalents. 
2005). For isolated skin, ethanol concentrations around $60 \%$ and moderate solid-solvent ratio (Figure 1c), and temperature $\left(65^{\circ} \mathrm{C}\right)$ generated better phenolic compounds recovery $(p<$ 0.001). These results are compatible to those reported for chestnut bur (Vázquez et al., 2012), in which reducing the solvent concentration (from $90 \%$ to $50 \%$ ) and increasing the temperature (from 25 to $75^{\circ} \mathrm{C}$ ) yielded higher total phenolic contents over $30 \mathrm{~min}$ of extraction.

Effect of the extraction factors on antioxidant capacity (ABTS, DPPH and FRAP)

According to the ABTS assay, increases in solvent concentration (75\%) and temperature (above $65^{\circ} \mathrm{C}$ ) (Figure $1 d)$, and the solid-solvent ratio of $5 \mathrm{mg} \mathrm{mL}^{-1}(p<0.01)$ improved the antioxidant capacity of whole baru almond. For baru almond without skin, lower ethanol concentration and solid-solvent ratio caused significant increases in antioxidant capacity (Figure 1e). For isolated skin, improved antioxidant capacity was observed with an ethanol concentration of $40 \%$, the solid-solvent ratio of $0.2 \mathrm{mg} \mathrm{mL}^{-1}$, and a temperature of $65^{\circ} \mathrm{C}$ (Figure 1f).

Regarding the DPPH assay, the solid-solvent ratio of $2 \mathrm{mg}$ $\mathrm{mL}^{-1}$ yielded better results for antioxidant capacity than did other rates, in whole baru almond (Figure 1g). The ethanol concentration of $90 \%$ and a temperature of $65{ }^{\circ} \mathrm{C}$ were positively associated with increases in the antioxidant capacity of whole baru almond $(p \leq 0.02)$. For baru almond without skin, a solid-solvent ratio lower than $20 \mathrm{mg} \mathrm{mL}^{-1}$ and a low concentration of ethanol (65\%) resulted in antioxidant capacity above $26 \mu \mathrm{mol} \mathrm{TE} \mathrm{g}{ }^{-1}$ (Figure 1h). For isolated skin, ethanol concentrations between $40 \%$ and $90 \%$ and temperature of $65{ }^{\circ} \mathrm{C}$ yielded a higher antioxidant capacity (above $3000 \mu \mathrm{mol}$ $\mathrm{TE} \mathrm{g}^{-1}$ ) than did other experimental conditions (Figure 1i).

The ethanol concentration of $60 \%$ and the solid-solvent ratio of $2 \mathrm{mg} \mathrm{mL}^{-1}$ (Figure $1 \mathrm{j}$ ) generated an antioxidant

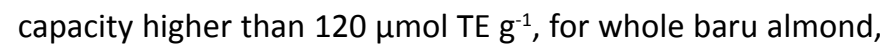
according to the FRAP assay. For baru almond without skin, ethanol concentration below $65 \%$ and the solid-solvent ratio of $40 \mathrm{mg} \mathrm{mL}^{-1}$ (Figure 1k), after extraction for $35 \mathrm{~min}$, showed an antioxidant capacity above $4 \mu \mathrm{mol} \mathrm{TE} \mathrm{g}^{-1}(\mathrm{p}<0.0006)$. For isolated skin (Figure 1l), the ethanol concentration of $60 \%$ at a temperature above $65 \stackrel{\circ}{\circ}$ and a solid-solvent ratio below 0.4 $\mathrm{mg} \mathrm{mL}^{-1}$ featured an antioxidant capacity higher than 1800 $\mu \mathrm{mol} \mathrm{TE} \mathrm{g}^{-1}(\mathrm{p}<0.04)$, over 30 min of extraction.

In our study, three antioxidant capacity assays were used because of their different principles and fundamentals, as well as the variety of the antioxidant compounds present in the samples (Fernandes et al., 2015; Siqueira et al., 2015). Furthermore, the use of at least two in vitro methods to estimate the antioxidant capacity is recommended in order to ensure reliable results (López-Alarcón \& Denicola, 2013).

\section{Optimized extraction conditions}

The ethanol concentrations of $40 \%$ and $80 \%$ showed better phenolic compounds' recovery and antioxidant capacity than did other concentrations for all samples analyzed (Table 3). Vázquez et al. (2012) reported similar results in the chestnut bur, in which ethanol and methanol concentrations from $50 \%$ to $90 \%$ yielded high phenolic contents.

Lower solid-solvent ratios improved the phenolic compounds' recovery and antioxidant capacity in all samples (Table 3). These results are consistent with those observed for peanut skin (Ballard et al., 2010), in which lower mass generated better phenolic compounds' recovery and antioxidant capacity, as determined by ORAC assay. This finding can be explained by increases in the diffusion coefficient of the solution, since lower mass concentrations increase the contact surface and the sample solubility, and thus optimize the extraction process (Shi et al., 2005).

The extraction time of $34 \mathrm{~min}$ generated total phenolic contents higher than those observed in other times, for baru almond without skin, and temperature of $85^{\circ} \mathrm{C}$ optimized the extraction of the phenolics in whole baru almond, and of 66 ${ }^{\circ} \mathrm{C}$, in the isolated skin (Table 3). In the pistachio skin, $45 \mathrm{~min}$ of the polyphenols extraction was more effective than shorter extraction times (Rajaei et al., 2010).

The global desirability test was suitable for simultaneously predicting ideal conditions of independent and dependent variables (total phenolic content and antioxidant capacity). According to the desirability range (between 0 and 1 ) proposed by Candioti et al. (2014), our results (0.80-0.99, Table 3) confirm the reliability of the statistical model generated.

\section{Predicted and experimental results}

The total phenolic content of whole baru almond evaluated under optimized conditions (Table 4) was higher than that reported in the literature ( $388 \mathrm{mg} \mathrm{GAE} 100 \mathrm{~g}^{-1}$ ) (Siqueira et al., 2015). Moreover, the total phenolic content of whole baru almond was higher than those reported for peanut (430 mg GAE $100 \mathrm{~g}^{-1}$ ) and almond ( $87.5 \mathrm{mg} \mathrm{GAE} 100 \mathrm{~g}^{-1}$ ) (Ozer, 2017). According to the DPPH assay (Table 4), whole baru almond showed an antioxidant capacity higher than

Table 3. Optimized extraction factors for total phenolic content and antioxidant capacity of whole baru almond, baru almond without skin, and isolated skin.

\begin{tabular}{lccc}
\multicolumn{1}{c}{ Factor } & Whole baru almond & Baru almond without skin & Isolated skin \\
\hline Ethanol concentration $(\%)$ & 79.09 & 67.62 & 40.00 \\
Solid-solvent ratio $\left(\mathrm{mg} \mathrm{mL}^{-1}\right)$ & 2.0 & 20.0 & 0.2 \\
Temperature $\left({ }^{\circ} \mathrm{C}\right)$ & 85.00 & $\mathrm{NS}$ & 66.25 \\
Time $(\min )$ & $\mathrm{NS}$ & 34 & $\mathrm{NS}$ \\
Desirability $(\mathrm{D})$ & 0.80 & 0.99 & 0.88 \\
\hline
\end{tabular}

NS: non-significant factor $(p>0.05)$ in the fractional factorial $2^{4-1}$ design. 
Table 4. Experimental (exp) and predicted (pred) results of total phenolic content ( $\mathrm{mg} \mathrm{GAE} 100 \mathrm{~g}^{-1}$ ) and antioxidant capacity $\left(\mu \mathrm{mol} \mathrm{TE} \mathrm{g}^{-1}\right)$ of whole baru almond, baru almond without skin, and isolated skin.

\begin{tabular}{|c|c|c|c|c|c|c|c|c|}
\hline \multirow{2}{*}{ Baru almond } & \multicolumn{2}{|c|}{ TPC } & \multicolumn{2}{|c|}{ ABTS } & \multicolumn{2}{|c|}{ DPPH } & \multicolumn{2}{|c|}{ FRAP } \\
\hline & exp & pred & $\exp$ & pred & exp & pred & exp & pred \\
\hline Whole & 561.98 & 609.24 & 170.72 & 169.82 & 259.10 & 254.99 & 144.49 & 155.63 \\
\hline Without skin & 62.52 & 67.20 & 5.91 & 6.47 & 24.20 & 26.01 & 4.82 & 4.60 \\
\hline Skin & $9,729.59$ & $9,765.46$ & $1,620.23$ & $1,651.04$ & $3,284.71$ & $3,229.11$ & $2,096.73$ & $2,069.10$ \\
\hline
\end{tabular}

TPC: total phenolic content; GAE: gallic acid equivalents; TE: Trolox equivalents; ABTS: 2,2'-Azino-bis(3-ethylbenzothiazoline-6-sulfonic acid); DPPH: 2,2-Diphenyl-1-picrylhydrazyl FRAP: Ferric Reducing Antioxidant Power.

those reported for baru almond $\left(67 \mu \mathrm{mol} \mathrm{TE} \mathrm{g}^{-1}\right)$ (Siqueira et al., 2015), and for single-roasted pistachio $\left(9.76 \mu \mathrm{mol} \mathrm{TE}^{-1}\right)$ (Rodríguez-Bencomo et al., 2015). Regarding the FRAP assay, the value reported for roasted baru almond $\left(126.8 \mu \mathrm{mol} \mathrm{TE}^{-1}\right)$ (Santiago et al., 2018) was lower than that observed in our study for whole baru almond (Table 4).

Previous report with baru almond without skin (Lemos et al., 2012) showed a higher concentration of phenolic compounds (111.3 mg GAE $100 \mathrm{~g} \mathrm{~g}^{-1}$ ) and lower antioxidant capacity $\left(1.39 \mu \mathrm{mol} \mathrm{TE} \mathrm{^{-1 } )}\right.$ than those of the present study (Table 4). Nevertheless, the polyphenols content of the baru almond without skin (Table 4) was higher than that reported for chestnut bur (43 mg GAE $100 \mathrm{~g}^{-1}$ ) (Vázquez et al., 2012).

The total phenolic content of the isolated skin was similar to that observed in the roasted pistachio skin $(10,400 \mathrm{mg}$ GAE $100 \mathrm{~g}^{-1}$ ) (Grace et al. 2016), but significantly higher than those reported for almond skin (703 mg GAE $100 \mathrm{~g}^{-1}$ ) (Smeriglio et al., 2016). The isolated skin of the baru almond also showed an antioxidant capacity significantly higher than those of the almond skin (ABTS $=69 \mu \mathrm{mol} \mathrm{TE} \mathrm{g}{ }^{-1} ;$ ORAC $=162 \mu \mathrm{mol} \mathrm{TE} \mathrm{g}^{-1}$ ) (Smeriglio et al., 2016). To our knowledge, this is the first report about the total phenolic content and antioxidant capacity of the baru almond skin. Here we confirmed our hypothesis that the high content of polyphenols of whole baru almond is mainly due to its skin, a rich source of these compounds. Thus, we recommend the exploitation of this agro-industrial by-product as a source of natural antioxidants, and the use of whole baru almond and its skin in the formulation of enriched foods and nutraceuticals with antioxidant properties.

\section{Conclusions}

The Box-Behnken design associated with the response surface methodology was suitable for optimizing the extraction conditions of the phenolic compounds in the baru almond and by-products.

On optimized extraction conditions, whole baru almond (with skin) showed a high phenolic content and antioxidant capacity compared to other oilseeds, and the baru almond skin featured about $10 \%$ of phenolics and a very high antioxidant capacity.

Therefore, we recommend the consumption of whole baru almond, and the use of its skin in different healthy food systems and nutraceuticals as a rich source of natural antioxidants.

\section{Acknowledgements}

The authors would like to thank Lidiane B. Muniz, Ph.D., for the support in the research design. They also gratefully acknowledge the financial support provided by FAPEG (Fundação de Amparo à Pesquisa do Estado de Goiás, Brazil, process number: 201210267001132) and a research scholarship granted by CAPES (Coordenação de Aperfeiçoamento de Pessoal de Nível Superior, Brazil).

\section{Literature Cited}

Ballard, T. S.; Mallikarjunan, P.; Zhou, K.; O'Keefe, S. Microwaveassisted extraction of phenolic antioxidant compounds from peanut skins. Food Chemistry, v. 120, n. 4, p. 1185-1192, 2010. https://doi.org/10.1016/j.foodchem.2009.11.063.

Benzie, I. F. F.; Strain, J. J. The ferric reducing ability of plasma (FRAP) as a measure of "antioxidant power": the FRAP assay. Analytical Biochemistry, v. 239, n. 1, p. 70-76, 1996. https://doi. org/10.1006/abio.1996.0292.

Bodoira, R.; Maestri, D. Phenolic compounds from nuts: extraction, chemical profiles, and bioactivity. Journal of Agricultural and Food Chemistry, v. 68, n. 4, p. 927-942, 2020. https://doi.org/10.1021/ acs.jafc.9b07160.

Bodoira, R.; Velez, A.; Rovetto, L.; Ribotta, P.; Maestri, D.; Martínez, M. Subcritical fluid extraction of antioxidant phenolic compounds from pistachio (Pistacia vera L.) nuts: experiments, modeling, and optimization. Journal of Food Science, v. 84, n. 5, p. 963-970, 2019. https://doi.org/10.1111/1750-3841.14507.

Brand-Williams, W.; Cuvelier, M. E.; Berset, C. Use of a free radical method to evaluate antioxidant activity. LWT- Food Science and Technology, v. 28, n. 1, p. 25-30, 1995. https://doi.org/10.1016/ S0023-6438(95)80008-5.

Candioti, L. V.; Zan, M.M.; Cámara, M. S.; Goicoechea, H. C. Experimental design and multiple response optimization. Using the desirability function in analytical methods development. Talanta, v. 124, p. 123-138, 2014. https://doi.org/10.1016/j. talanta.2014.01.034.

Chavan, Y.; Singhal, R. S. Ultrasound-assisted extraction (UAE) of bioactives from arecanut (Areca catechu L.) and optimization study using response surface methodology. Innovative Food Science and Emerging Technologies, v. 17, p. 106-113, 2013. https://doi.org/10.1016/j.ifset.2012.10.001.

Fernandes, D. C.; Alves, A. M.; Castro, G. S. F.; Jordão Junior, A.A.; Naves, M. M. V. Effects of baru almond and Brazil nut against hyperlipidemia and oxidative stress in vivo. Journal of Food Research, v. 4, n. 4, p. 38-46, 2015. https://doi.org/10.5539/jfr. v4n4p38. 
Grace, M. H.; Esposito, D.; Timmers, M. A.; Xiong, J.; Yousef, G.; Komarnytsky, S.; Lila, M. A. In vitro lipolytic, antioxidant and anti-inflammatory activities of roasted pistachio kernel and skin constituents. Food and Function, v. 7, n. 10, p. 4285-4298, 2016. https://doi.org/10.1039/c6fo00867d.

Hossain, M. B.; Barry-Ryan, C.; Martin-Diana, A. B.; Brunton, N. P. Optimisation of accelerated solvent extraction of antioxidant compounds from rosemary (Rosmarinus officinalis L.), marjoram (Origanum majorana L.) and oregano (Origanum vulgare L.) using response surface methodology. Food Chemistry, v. 126 , n. 1, p. 339-346, 2011. https://doi.org/10.1016/j. foodchem.2010.10.076.

Lemos, M. R. B.; Siqueira, E.M.A.; Arruda, S. F.; Zambiazi, R. C. The effect of roasting on the phenolic compounds and antioxidant potential of baru nuts [Dipteryx alata Vog.]. Food Research International, v. 48, n. 2, p. 592-597, 2012. https://doi. org/10.1016/j.foodres.2012.05.027.

López-Alarcón, C.; Denicola, A. Evaluating the antioxidant capacity of natural products: a review on chemical and cellular-based assays. Analytica Chimica Acta, v. 763, p. 1-10, 2013. https://doi. org/10.1016/j.aca.2012.11.051.

Lundstedt, T.; Seifert, E.; Abramo, L.; Thelin, B.; Nystrom, A.; Pettersen, J. et al. Experimental design and optimization. Chemometrics and Intelligent Laboratory Systems, v. 42, n. 1-2, p. 3-40, 1998. https://doi.org/10.1016/S0169-7439(98)00065-3.

Odabas, H. I.; Koca, I. Application of response surface methodology for optimizing the recovery of phenolic compounds from hazelnut skin using different extraction methods. Industrial Crops and Products, v. 91, p. 114-124, 2016. https://doi.org/10.1016/j. indcrop.2016.05.033.

Ozer, H. K. Phenolic compositions and antioxidant activities of Maya nut (Brosimum alicastrum): comparison with commercial nuts. International Journal of Food Properties, v. 20, n. 11, p. 27722781, 2017. https://doi.org/10.1080/10942912.2016.1252389.

Pulido, R.; Bravo, L.; Saura-Calixto, F. Antioxidant activity of dietary polyphenols as determined by a modified ferric reducing/ antioxidant power assay. Journal of Agricultural and Food Chemistry, v. 48, n. 8, p. 3396-3402, 2000. https://doi. org/10.1021/jf9913458.

Rajaei, A.; Barzegar, M.; Hamidi, Z.; Sahari, M.A. Optimization of extraction conditions compounds from pistachio (Pistachia vera) green hull through response surface method. Journal of Agricultural Science and Technology, v. 12, n. suppl., p. 605-615, 2010. https://jast.modares.ac.ir/article-23-6401-en.pdf. 29 Mar. 2020.
Re, R.; Pellegrini, N.; Proteggente, A.; Pannala, A.; Yang, M.; RiceEvans, C. Antioxidant activity applying an improved ABTS radical cation decolorization assay. Free Radical Biology \& Medicine, v. 26, n. 9-10, p. 1231-1237, 1999. https://doi.org/10.1016/S08915849(98)00315-3.

Rodríguez-Bencomo J. J.; Kelebek, H.; Sonmezdag, A. S.; RodríguezAlcalá, L. M.; Fontecha, J.; Selli, S. Characterization of the aromaactive, phenolic, and lipid profiles of the pistachio (Pistacia vera I.) nut as affected by the single and double roasting process. Journal of Agricultural and Food Chemistry, v. 63, n. 35, p. 78307839, 2015. https://doi.org/10.1021/acs.jafc.5b02576.

Santiago, G. L.; Oliveira, I. G.; Horst, M. A.; Naves, M. M. V.; Silva, M. R. Peel and pulp of baru (Dipteryx Alata Vog.) provide high fiber, phenolic content and antioxidant capacity. Food Science and Technology, v. 38, n. 2, p. 244-249, 2018. https://doi. org/10.1590/1678-457X.36416.

Shi, J.; Nawaz, H.; Pohorly, J.; Mittal, G.; Kakuda, Y.; Jiang, Y. Extraction of polyphenolics from plant material for functional foodsengineering and technology. Food Reviews International, v. 21, n. 1, p. 139-166, 2005. https://doi.org/10.1081/FRI-200040606.

Singleton, V. L.; Rossi, J. A. Colorimetry of total phenolics with phosphomolybdic-phosphotungstic acid reagents. American Journal of Enology and Viticulture, v. 16, n.3, p. 144-158, 1965. https://www.ajevonline.org/content/16/3/144. 29 Mar. 2020.

Siqueira, A.P.S.; Pacheco, M. T. B.; Naves, M. M. V. Nutritional quality and bioactive compounds of partially defatted baru almond flour. Food Science and Technology, v. 35, n. 1, p. 127-132, 2015. https://doi.org/10.1590/1678-457X.6532.

Smeriglio, A.; Mandalari, G.; Bisignano, C.; Filocamo, A.; Barreca, D.; Bellocco, E.; Trombetta, D. Polyphenolic content and biological properties of Avola almond (Prunus dulcis Mill. D.A. Webb) skin and its industrial byproducts. Industrial Crops and Products, v. 83, p. 283-293, 2016. https://doi.org/10.1016/j. indcrop.2015.11.089.

Sousa, A. G. O.; Fernandes, D. C.; Alves, A. M.; Freitas, J. B.; Naves, M. M. V. Nutritional quality and protein value of exotic almonds and nut from the Brazilian Savanna compared to peanut. Food Research International, v. 44, n. 7, p. 2319-2325, 2011. https:// doi.org/10.1016/j.foodres.2011.02.013.

Vázquez, G.; Fernández-Agulló, A.; Gómez-Castro, C.; Freire, M. S.; Antorrena, G.; González-Álvarez, J. Response surface optimization of antioxidants extraction from chestnut (Castanea sativa) bur. Industrial Crops and Products, v. 35, n. 1, p. 126-134, 2012. https://doi.org/10.1016/j.indcrop.2011.06.022. 